\title{
PELUANG DAN TANTANGAN MERGER BANK SYARIAH MILIK NEGARA DI INDONESIA PADA MASA PANDEMI COVID-19
}

\author{
Alfany Arga Alil Fiqri', Minerva Maharani Azzahra², \\ Khansa Dzakiyah Branitasandini ${ }^{3}$, Laila M. Pimada ${ }^{4}$ \\ 1,2,3,4 Universitas Brawijaya, Indonesia
}

$\triangle$ Corresponding Author:

Nama Penulis: Laila M. Pimada

E-mail: lailapimada@ub.ac.id

\section{Abstract}

The existence of COVID-19 in Indonesia had an impact on economy, including banking sector. However, sharia banking sector didn't show a positive trend. However, even though sharia banking shows a positive trend, penetration rate of Islamic banking market in Indonesia is still relatively small when compared to conventional banking. That has made government decide to make a merger policy in state-owned sharia banking in hope that it can increase market penetration in Indonesia. This article is written to analyze about opportunities and challenges of merger policy for sharia banking considering the large role of sharia banking in improving country's economy. On the other hand, this policy was implemented in the midst of the COVID-19 pandemic. This article uses qualitative data analysis with descriptive methods and through a literature study approach. The data analysis focuses on the opportunities and challenges of the sharia banking merger policy by Indonesian's government. Researchers use secondary data as a source for making articles. Based on research results, the formation of Bank Syariah Indonesia (BSI) as a result of merger provides many opportunities such as increasing assets, expanding market penetration, and operating cost efficiency. Meanwhile, financing and operational risk are two big challenges that need attention. This study contributes as inputs for stakeholders' decisions in developing Islamic bank and finance.

Keywords: Merger; Sharia Banking; COVID-19.

Abstrak

Adanya pandemi COVID-19 di Indonesia memberikan dampak yang signifikan terhadap perekonomian, termasuk sektor perbankan. Namun tidak dengan perbankan syariah yang malah menunjukkan tren positif. Akan tetapi, walaupun perbankan syariah menunjukkan tren positif, tingkat penetrasi market perbankan syariah di Indonesia masih tergolong kecil jika dibandingkan dengan perbankan konvensional. Hal itu yang membuat pemerintah memutuskan untuk membuat kebijakan merger pada perbankan syariah milik negara dengan harapan bisa meningkatkan penetrasi pasar di Indonesia. Artikel ini disusun untuk menganalisis terkait peluang dan tantangan dari kebijakan merger bagi perbankan syariah menimbang besarnya peran perbankan syariah dalam meningkatkan perekonomian negara. Di sisi lain, kebijakan ini dilaksanakan di tengah pandemi COVID-19. Artikel ini menggunakan analisis data kualitaitf dengan metode deskriptif dan 
melalui pendekatan studi literatur. Analisis data berfokus pada peluang dan tantangan dari kebijakan merger bank syariah oleh pemerintah Indonesia. Peneliti menggunakan data sekunder sebagai sumber pembuatan artikelnya. Berdasarkan hasil penelitian, pembentukan Bank Syariah Indonesia (BSI) yang merupakan hasil dari penggabungan memberikan banyak peluang seperti peningkatan aset, perluasan penetrasi pada pasar, serta efisiensi biaya operasional. Sementara itu, risiko pembiayaan dan operasional merupakan dua tantangan besar yang perlu diperhatikan. Penelitian ini diharapkan dapat berkontribusi sebagai input bagi para stakeholder dalam mengambil kebijakan yang berfokus pada pengembangan perbankan dan keuangan Islam.

Kata kunci: Merger; Perbankan Syariah; COVID-19.

\section{PENDAHULUAN}

Menyebarnya COVID-19 di Indonesia membawa dampak yang begitu luas di berbagai sektor, tidak hanya berdampak pada sektor kesehatan saja. Salah satu dampak yang terkena signifikan yaitu dari segi perekonomian seperti yang terdapat pada sektor korporasi, UMKM, rumah tangga, dan sektor keuangan (Hartomo, 2020). Bank Indonesia (BI) sebagai bank sentral di Indonesia berupaya untuk menjaga kestabilan nilai tukar agar rupiah tidak mengalami penekanan yang berlebihan. Beberapa langkahnya seperti mulai dari menggunakan cadangan devisa untuk mengundang investor masuk ke Indonesia hingga mengurangi Giro Wajib Minimum (GWM) dari perbankan umum dari semula 8\% turun menjadi 4\% (Goutama, 2020). Kebijakan BI tersebut membawa dampak yang signifikan bagi perbankan sebagai pemeran penting dalam perekonomian di Indonesia (PS, 2018) karena berkat turunnya GWM menjadikan perbankan bisa meningkatkan penyaluran pembiayaan salah satunya yang terjadi di perbankan syariah.

Berkaitan dengan industri perbankan, dilihat dari segi aset, jumlah penyaluran pembiayaan, serta Dana Pihak Ketiga (DPK), sektor perbankan syariah di Indonesia telah tumbuh dan berkembang dengan baik (Alfi, 2020). Dari data yang diambil pada laman milik Otoritas Jasa Keuangan (OJK), tepatnya pada juni 2020, kekayaan milik perbankan syariah di Indonesia mengalami pertumbuhan sebesar 9,22\% (sekitar Rp545,39 triliun yoy). Adapun jumlah penyaluran pembiayaan pada perbankan syariah naik menjadi Rp377,53 triliun (tumbuh sebesar 10,13\%), sementara pertumbuhan dari DPK menjadi Rp430,21 triliun (tumbuh sebesar 8,99\%).

Meskipun pertumbuhan dari perbankan syariah di Indonesia berstatus positif, penetrasi market perbankan syariah tergolong masih kecil jika dibandingkan dengan penetrasi pasar perbankan konvensional. Tingkat penetrasi perbankan syariah Indonesia pada 2020 hanya sebesar 6,18\%, sedangkan sisanya dimiliki oleh perbankan konvensional (Alfi, 2020). Berangkat dari permasalahan itulah pemerintah kemudian menyepakati adanya rencana merger pada perbankan syariah pelat merah di Indonesia, yaitu Bank Negara Indonesia Syariah (BNIS), Bank Syariah Mandiri (BSM), serta Bank Rakyat Indonesia Syariah (BRIS) (Wiratmini, 2020) yang menyandang nama baru sebagai Bank Syariah Indonesia (BSI). Dengan adanya merger ini diharapkan bisa menghasilkan aset yang lebih besar lagi 
sehingga bisa memperbesar tingkat penetrasi pasar di penjuru Indonesia. Jika ketiga bank syariah ini telah resmi melakukan merger, maka perbankan syariah hasil merger diperkirakan akan memiliki aset sebesar Rp220-Rp225 triliun (Wiratmini, 2020).

Sementara itu, adanya merger pada perusahaan tersebut ternyata juga akan menimbulkan banyak tantangan mengingat merger dilakukan di tengah bencana pandemi COVID-19 berlangsung seperti risiko pembiayaan dan risiko operasional (Lokadata.id, 2020). Dalam rangka memberikan tambahan literasi terkait fenomena merger yang masih baru ini, penulis melakukan analisa kritis terhadap peluang dan tantangan dibentuknya BSI. Secara lebih rinci, dari hasil penelitian ini diharapkan dapat menyediakan informasi terkait permasalahan-permasalahan yang muncul dari kebijkan merger sehingga para stakeholder dapat meminimalkan resiko dan memanfaatkan peluang yang ada untuk memaksimalisasi pertumbuhan perbankan syariah di Indonesi.

\section{KAJIAN PUSTAKA}

\section{COVID-19: Dampak Terhadap Ekonomi dan Sosial}

Coronavirus disease 2019 (COVID-19) atau biasa dikenal masyarakat luas dengan sebutan virus corona merupakan suatu penyakit yang dapat menular melalui droplets dari orang yang terinfeksi bersin ataupun batuk. Virus corona ini disebabkan oleh protein sejenis corona yang masih satu kelompok dengan SARS (Severe Acute Respiratory Syndrome) yaitu SARS-Cov2 atau Coronavirus-2 (Kementerian Kesehatan Republik Indonesia, 2020). Penyebaran virus ini dimulai dari Wuhan, ibu kota dari Provinsi Hubei, China pada akhir bulan Desember tahun 2019 yang menyebabkan terjadinya pandemi global. Hingga saat ini penyakit COVID-19 ini sudah tersebar luas ke berbagai negara dengan total kasus pertanggal 18 Desember ini sejumlah 74.887.390 jiwa dan korban yang meninggal sebanyak 1.660.281 jiwa (Google News, 2020). Pemerintah di berbagai negara pun akhirnya membuat kebijakan lockdown dan social distancing yang berupaya untuk memberhentikan penyebaran dari virus ini.

Indonesia merupakan satu dari ratusan negara yang terindikasi virus corona. Hingga rabu, tanggal 16 Desember 2020 pukul 18.25 WIB, total kasus sebanyak 636.154 jiwa dan korban yang meninggal sebanyak 19.248 jiwa (Line Siaga, 2020). Pada bulan Maret tahun 2020, virus corona pertama kali ditemukan di Indonesia sebanyak dua kasus. Akhirnya, pada tanggal 31 Maret 2020 pemerintah resmi membuat peraturan mengenai pedoman Pembatasan Sosial Berskala Besar atau biasa masyarakat luas menyebutnya dengan PSBB sebagai wujud implementasi dari kebijakan social distancing (Pradana et al., 2020) yang bertujuan untuk mempercepat penanganan virus 
corona ini. Kebijakan PSBB ini antara lain berupa kegiatan di tempat kerja dan sekolah yang dirumahkan sehingga dikenal dengan sebutan Work From Home (WFH) bagi para pekerja dan online school bagi para pelajar, juga pembatasan dalam kegiatan yang terkait dengan keagamaan. Kemudian kegiatan yang dilakukan di tempat umum juga dibatasi.

Selain berdampak pada sektor kesehatan dan kehidupan sosial, adanya COVID-19 ini juga berdampak pada sektor ekonomi. Beberapa permasalahan perekonomian yang muncul akibat dari pandemi ini adalah sebagai berikut:

1) Peningkatan angka Pemutusan Hubungan Kerja (PHK) dan juga pemulangan karyawan/pekerja yang signifikan. Laju peningkatannya telah menyentuh angka 1,2 juta jiwa, bahkan lebih (Kementerian Ketenagakerjaan Republik Indonesia, 2020). Dari jumlah tersebut, sebanyak 10\% pekerja mengalami PHK, sementara sisanya dipulangkan. Sebanyak lebih dari 1 juta jiwa adalah pekerja resmi, sementara 200 ribu tepatnya 265 ribu jiwa sebagai pekerja pada sektor informal.

2) Purchasing Managers Index (PMI) manufaktur yang merupakan indikator kesehatan ekonomi dalam sektor manufaktur bertujuan untuk memberi informasi mengenai kondisi bisnis pada saat ini kepada pengambil keputusan perusahaan, analis dan manajer pembelian (The Global Economy, 2020). PMI Manufacturing Indonesia mengalami penurunan yang sangat signifikan bahkan pada bulan April 2020 telah mencapai titik terendah dari tingkatan yang telah dijangkau selama tahun 2020, yaitu mencapai level 27,5. PMI ini berisi tentang penjelasan mengenai kinerja dari suatu industri manufaktur.

3) Impor pada Oktober 2020 turun sebesar $26,9 \%$ secara yoy (year on year) (Bank Indonesia, 2020).

4) Laju inflasi pada bulan Januari hingga Oktober 2020 sebesar 0,95\%, sementara tingkat inflasi dari tahun ke tahun/yoy (Oktober 2020 terhadap Oktober 2019) sebanyak 1,44\%. Laju inflasi dapat dilihat pada Tabel 1.

5) Melambatnya laju pertumbuhan ekonomi di Indonesia yang dimulai pada Triwulan ke-IV tahun 2019. Fenomena ini disebabkan oleh adanya kebijakan pemerintah untuk menerapkan protokol kesehatan salah satunya dengan mengesahkan Peraturan Pemerintah nomor 21 Tahun 2020 tentang Pembatasan Sosial Berskala Besar dalam Rangka Percepatan Penanganan Corona Virus Disease 2019 (COVID-19) (Badan Pemeriksa Keuangan, 2020). Namun, pada Triwulan ke-II tahun 2020, laju pertumbuhan ekonomi kembali meningkat. Fenomena ini bisa terjadi karena pemerintah telah mulai memperbaiki kondisi perekonomian yang ada di Indonesia. Selengkapnya bisa dilihat dalam Tabel 2 dan Gambar 1. 
Alfany A.A. Fiqri: Peluang dan Tantangan Merger Bank Syariah

Tabel 1. Tingkat Inflasi Bulanan Indonesia selama pandemi COVID-19 (Persen)

\begin{tabular}{lc}
\hline \multicolumn{1}{c}{ Periode } & Inflation Rate (\%) \\
\hline Maret 2020 & 2,96 \\
April 2020 & 2,67 \\
Mei 2020 & 2,19 \\
Juni 2020 & 1,96 \\
Juli 2020 & 1,54 \\
Agustus 2020 & 1,32 \\
September 2020 & 1,42 \\
Oktober 2020 & 1,44 \\
November 2020 & 1,59 \\
\hline umber: Bank Indonesia (2020)
\end{tabular}

Tabel 2. Laju Pertumbuhan Ekonomi Tahun 2019-2020

\begin{tabular}{cc}
\hline Periode (Kuartal) & PDB (yoy) \\
\hline I-2019 & $5,07 \%$ \\
II-2019 & $5,05 \%$ \\
III-2019 & $5,02 \%$ \\
IV-2019 & $4,97 \%$ \\
I-2020 & $2,97 \%$ \\
II-2020 & $-5,32 \%$ \\
III-2020 & $-3,49 \%$ \\
\hline Sumber: Badan Pusat Statistik (2020)
\end{tabular}

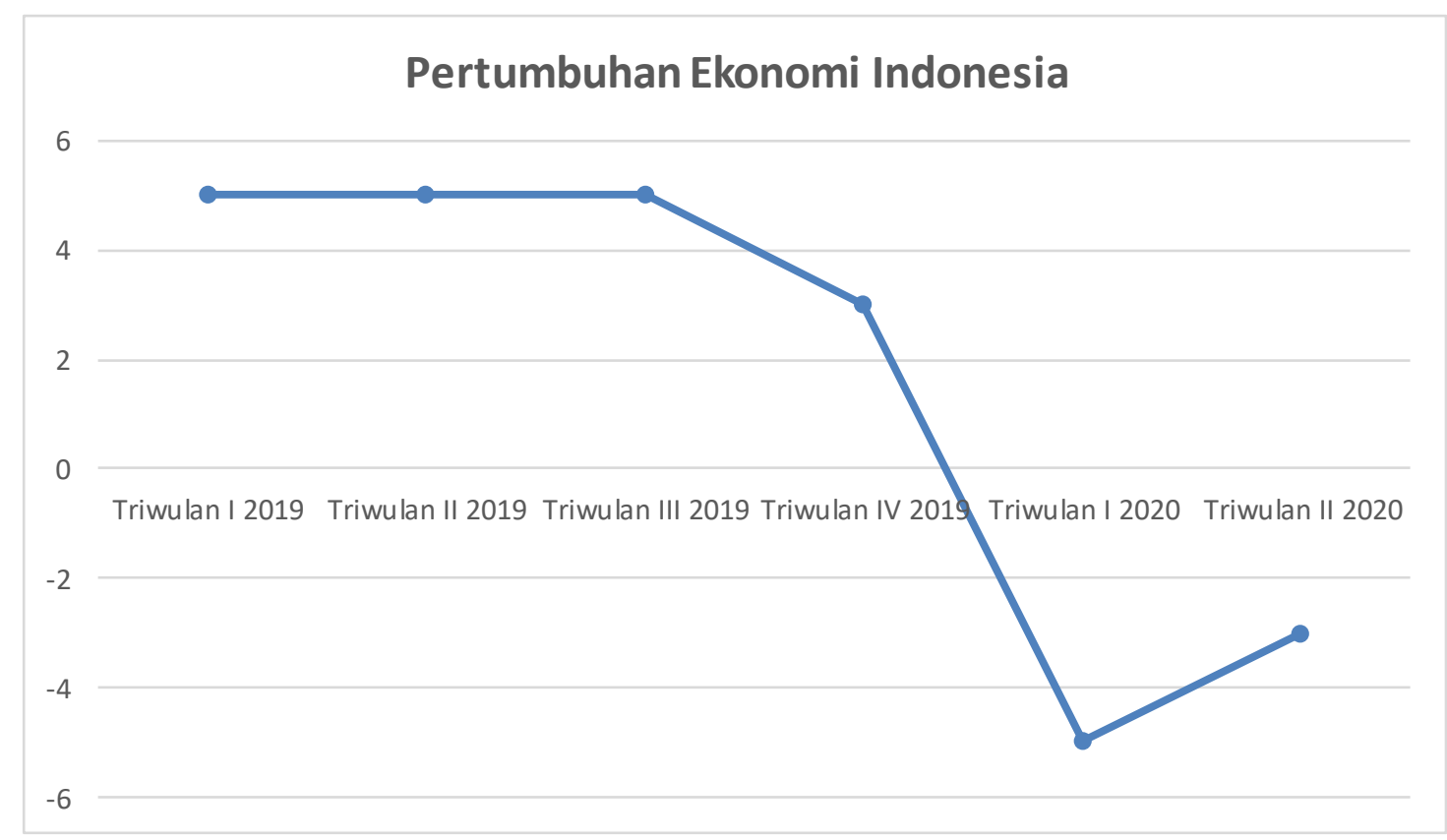

Gambar 1. Laju Pertumbuhan Ekonomi Tahun 2019-2020

Sumber: Badan Pusat Statistik (2020) 
Jika dikaitkan dengan masalah ekonomi, maka PDB adalah salah satu bagian yang penting dari perekonomian itu sendiri. Saat memasuki triwulan ke-II tahun 2020, total dari PDB atas dasar harga berlaku menyentuh angka Rp3.687,7 triliun. Akan tetapi, total dari PDB atas dasar harga invariabel dengan tahun dasar 2010 senilai Rp2.589,6 triliun. Berdasarkan hasil dari pengamatan tersebut, bisa disimpulkan bahwa perekonomian yang ada di Indonesia mengalami pertumbuhan negatif pada Kuartal ke-II 2020. Jika dibandingkan dengan perekonomian di Indonesia pada triwulan III-2019 yoy, perekonomian di Indonesia mengalami kenaikan pertumbuhan sebesar 3,49\% pada triwulan ke-III pada tahun 2020 (Badan Pusat Statistik, 2020).

\section{Konsep Merger}

Merger merupakan suatu usaha perombakan pada dua perusahaan sekaligus atau lebih dengan tujuan menggabungkannya yang salah satu dari perusahaan tersebut tetap berdiri dan menggunakan namanya. Bagi perusahaan lain yang bergabung akan dihentikan operasionalnya dan semua asetnya akan dipindahkan ke perusahaan penerima merger. Menurut M.E. Hitt, merger lebih condong pada proses akuisisi perusahaan terhadap perusahaan lain dan perusahaan yang diambil alih dalam keadaan berhenti beroperasi atau dibubarkan (Ibeng, 2021). Merger merupakan salah satu upaya strategis untuk membentuk badan usaha yang berdaya saing tinggi. Upaya strategis ini diharapkan dapat memperbaiki beberapa kinerja dari sistem keuangannya (Okalesa et al., 2014).

Dalam Peraturan Pemerintah Republik Indonesia Nomor 28 Tahun 1999 tentang merger, konsolidasi, dan akuisisi bank Presiden Republik Indonesia, dijelaskan bahwa merger merupakan penggabungan antara 2 bank atau lebih dengan mempertahankan salah satu bank untuk berdiri dan bank lainnya dibubarkan tanpa melikuidasi dahulu. Secara umum, merger perusahaan dapat diakibatkan oleh berbagai faktor diantaranya adalah untuk meningkatkan kemampuan perusahaan, diversifikasi dalam bidang usaha, meningkatkaan penguasaan terhadap pangsa pasar, mengurangi beban pajak yang ada dalam perusahaan, penilaian aset yang lebih rendah dari yang sesungguhnya, dan faktor yang terakhir yaitu untuk meningkatkan prestige dari perusahaan itu sendiri. Merger antara bank yang bermasalah dengan bank yang lebih kuat merupakan suatu pilihan terbaik karena dengan adanya bank lain yang lebih kuat tersebut akan menyelamatkan masalah likuiditas dari bank yang bermasalah karena memperoleh tambahan fresh money. Merger bank ditujukan untuk mengurangi labor expense, biaya overhead, serta menggabungkan antara kemampuan yang telah dicapai oleh rekan merger dan bertujuan untuk meminimalisir total cabang yang tumpang tindih 
dalam tingkat operasionalnya antara salah satu cabang dengan cabang yang lainnya (Ibeng, 2021).

Menurut Amalia \& Ika (2014), kebijakan merger ini penting dilakukan oleh perusahaan khususnya perusahaan perbankan mengingat masuknya era digital yang memberikan dampak berupa persaingan yang signifikan antar perusahaan perbankan. Kebijakan merger merupakan satu dari sekian banyak kebijakan eksternal yang dikeluarkan oleh perbankan yang berfungsi untuk mengembangkan strategi dalam berbisnis melalui teknik peningkatan nilai oleh perusahaan tersebut. Salah satu peningkatan nilai yang didapatkan oleh perbankan setelah melakukan kebijakan merger yaitu terjadi peningkatan kinerja finansial pada perbankan yang salah satu pembuktiannya dapat diuji melalui berbandingan rasio keuangan internal bank seperti ROA, CAR, LDR, dan NPL antara sebelum merger dengan sesudah merger (Usmany \& Badjra, 2019).

\section{Bank Syariah}

Berdasarkan UU Nomor 10 Tahun 1988 yang membahas tentang perbankan dijelaskan bahwa bank disebutkan sebagai badan usaha yang menghimpun dana dari masyarakat dalam bentuk simpanan dan menyalurkannya kepada masyarakat dalam bentuk kredit dan atau bentukbentuk lainnya dalam rangka meningkatkan taraf hidup masyarakat (Otoritas Jasa Keuangan, 2020a). Dalam menjalankan kegiatan usahanya, Indonesia telah membagi bank ke dalam dua bagian yaitu bank konvensional yang menjalani kegiatan operasionalnya tidak berlandaskan prinsip syariah islam namun hanya berdasarkan prinsip ekonomi pada umumnya. Kemudian ada bank syariah yang menjalankan operasionalnya berlandaskan syariah islam yang telah ditetapkan. Produk dalam bank syariah tidak menggunakan unsur riba, gharar, ataupun maysir. PT Bank Muamalat Indonesia merupakan bank syariah paling tua di Indonesia yang berdiri di akhir tahun 1991 tepatnya di tanggal 1 November dan resmi menjalankan kegiatan operasionalnya setelah 5 bulan berdiri tepatnya 1 Mei 1992 (Otoritas Jasa Keuangan, 2020d).

\section{METODE PENELITIAN}

Artikel ini menggunakan analisis data kualitaitf dengan metode deskriptif dan melalui pendekatan studi literatur. Penelitian kualitatif merupakan strategi penelitan yang lebih menekankan kata daripada kuantifikasi dalam pengumpulan dan analisa datanya (Bryman and Bell, 2003). Tujuan dari disusunnya artikel ini adalah untuk menganalisis terkait peluang dan tantangan dari kebijakan merger bagi perbankan syariah menimbang besarnya peran perbankan syariah dalam meningkatkan perekonomian negara, sedangkan di sisi lain terdapat polemik antar pihak. 
Analisis data kualitatif berfokus pada peluang dan tantangan dari kebijakan merger bank syariah oleh pemerintah Indonesia.

Peneliti menggunakan data sekunder sebagai sumber pembuatan artikelnya. Kebutuhan dari data sekunder ini penulis dapatkan melalui data yang disebarluaskan oleh tiga Bank Umum Syariah milik negara peserta merger yaitu ada Bank Syariah Mandiri (BSM), Bank Negara Indonesia Syariah (BNIS), serta Bank Rakyat Indonesia Syariah (BRIS). Adapun literatur, referensi, dan dokumen lainnya berupa jurnal penelitian terdahulu, buku elektronik, serta beberapa artikel dan berita yang terkait dengan pandemi COVID-19 dan rencana merger Bank Umum Syariah Milik Negara.

\section{HASIL DAN PEMBAHASAN}

\section{Kondisi Perbankan Syariah di Indonesia}

Perbankan syariah sebagai suatu lembaga distribusi keuangan (financial intermediary) (Sipangkar \& Sihaloho, 2020) di Indonesia saat ini tumbuh dengan pesat dengan dibuktikannya data dari Otoritas Jasa Keuangan (OJK) bahwa saat ini tercatat 14 Bank Umum Syariah (BUS), 20 Unit Usaha Syariah (UUS), dan 162 Bank Pembiayaan Rakyat Syariah (BPRS). Dari segi aset, perbankan syariah juga terus meningkat. Per Juni 2020, pertumbuhan aset perbankan syariah sebesar 9,22\% year on year dengan total aset sebesar 545,39 triliun.

Selain aset, Dana Pihak Ketiga (DPK) yang meliputi giro, tabungan, dan deposito juga meningkat sebesar 10,13\% y-o-y dengan total 430,21 triliun. Begitu juga dengan Pembiayaan Yang Diberikan (PYD) mengalami peningkatan sebesar 8,99\% dari Juni 2019 dengan total PYD sebesar 377,53 triliun. Jenis penggunaan dari PYD diantaranya konsumsi, sebanyak 45,02\%, modal kerja 31,60\%, dam investasi sebanyak 23,38\%. Pada semester ke-I tahun 2020, rata-rata dari Capital Adequacy Ratio (CAR) yang dimiliki oleh BUS sebesar 21,2\% yang merupakan sebuah peningkatan dari tahun sebelumnya sebesar 19,56\%. Sementara itu, rata-rata dari rasio kualitas pembiayaan (NPF) menurun sebesar 3,34\% dari tahun sebelumnya sebesar 3,36\% (Otoritas Jasa Keuangan, 2020e).

Sementara pada perbankan syariah peserta merger, per September 2020, BSM mencapai pertumbuhan bisnis yang berkualitas dengan meraih laba sebesar 1,077 triliun (naik signifikan jika dibandingkan dengan bulan september 2019 sebesar 810,573 miliyar). Dari segi kapasitas bisnis, BSM mencatat bahwa hingga akhir bulan September 2020, jumlah dari DPK sebesar Rp106,12 Triliun yang kemudian meningkat sebesar 17.26\% dari sebelumnya sebesar 90,49 Triliun per September 2019 (Bank Syariah Mandiri, 2020). Kemudian pada perbankan syariah peserta merger selanjutnya, BNIS meraih laba sebesar 387,02 miliyar per September 2020 
yang turun sebesar 16,22\% yoy per September 2019, sedangkan DPK meningkat sebanyak $21,76 \%$ sebesar 45,65 triliun dari sebelumnya sebesar 37,49 triliun. PYD dari BNIS juga meningkat sebesar 1,49\% menjadi 32,28 triliun dari sebelumnya sebesar 31,81 triliun (Bank Negara Indonesia Syariah, 2020). Disisi lain, BRIS juga mengalami peningkatan laba sebesar 238\% per September 2020 sebesar 190 miliar dari sebelumnya sebesar 56 miliyar pada September 2019, sedangkan dari DPK mengalami peningkatan sebesar 43\% yaitu sebesar 49 triliun dan PYD meningkat sebesar 47\% yaitu sebesar 40 triliun (Bank Rakyat Indonesia Syariah, 2020).

\section{Peluang Merger Bank Syariah}

Pertumbuhan aset dari perbankan syariah mengalami kenaikan yang signifikan selama tiga tahun terakhir dibandingkan dengan tahun 2015 yaitu dari yang sebelumnya 8,78\% menjadi lebih dari 12\%. Tidak terpaut secara signifikan, pertumbuhan perbankan konvensional dan perbankan syariah yang berada diangka 8,55\% dan 8,78\% hanya memiliki selisih 0,23\%. Pertumbuhan aset keseluruhan perbankan syariah mengalami tren meningkat dimulai tahun 2005 hingga 2019. Namun, pertumbuhan aset secara keseluruhan yang didorong oleh laju pertumbuhan majemuk tahunan investasi atau Compound Annual Growth Rate (CAGR) sebesar 15\% belum bisa meningkatkan angka penetrasi pasar perbankan syariah dengan pesat. Market share pada perbankan syariah tahun 2005 sampai dengan 2016 masih berkutat diangka 5\%.

Dari data diatas dapat disimpulkan bahwa perbankan syariah belum mampu melampaui pertumbuhan sektor secara keseluruhan dari sektor perbankan pada total aset secara intrinsik di sekitar angka 15-20\%. Maka, perlu diadakan strategi lain yang mendorong untuk meningkatkan penetrasi perkembangan industri perbankan syariah secara eksponensial yaitu dengan melakukan penggabungan atau merger. Dari adanya merger, perbankan syariah akan memiliki beberapa peluang diantaranya:

1. Peningkatan Aset Perbankan Syariah

Berdasarkan data statistik dari Otoritas Jasa Keuangan (OJK), tercatat sebanyak 14 BUS, 20 UUS, serta 162 BPRS yang telah terdaftar di OJK. Secara keseluruhan, total aset BUS dan UUS pada September 2020 mencapai 375,1 triliun dan UUS 186,6 triliun yang mengalami peningkatan jika dibandingkan pada September tahun 2019, BUS sebesar 325 triliun dan UUS 165,3 triliun. Gambar 2 sebagai berikut menunjukkan perkembangan total asset Bank Umum Syariah BUMN. Selanjutnya, Gambar 2 adalah proyeksi market share yang telah di proyeksikan oleh Komite Nasional Keuangan Syariah (KNKS) pada tahun 2019 . 


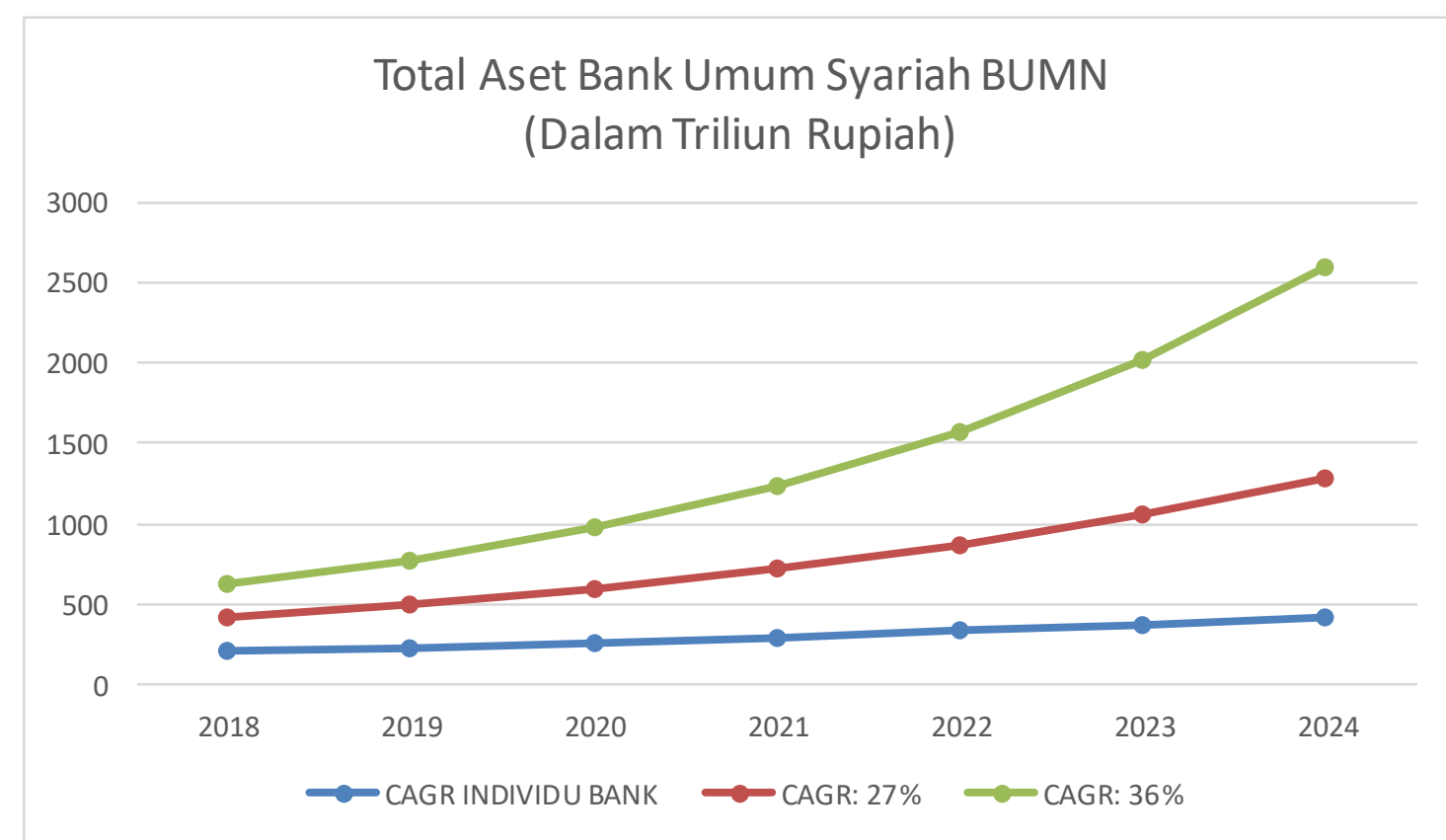

Gambar 2. Total Aset Bank Syariah Peserta Merger (Dalam Triliun Rupiah) Sumber: Komite Nasional Keuangan Syariah (2019)

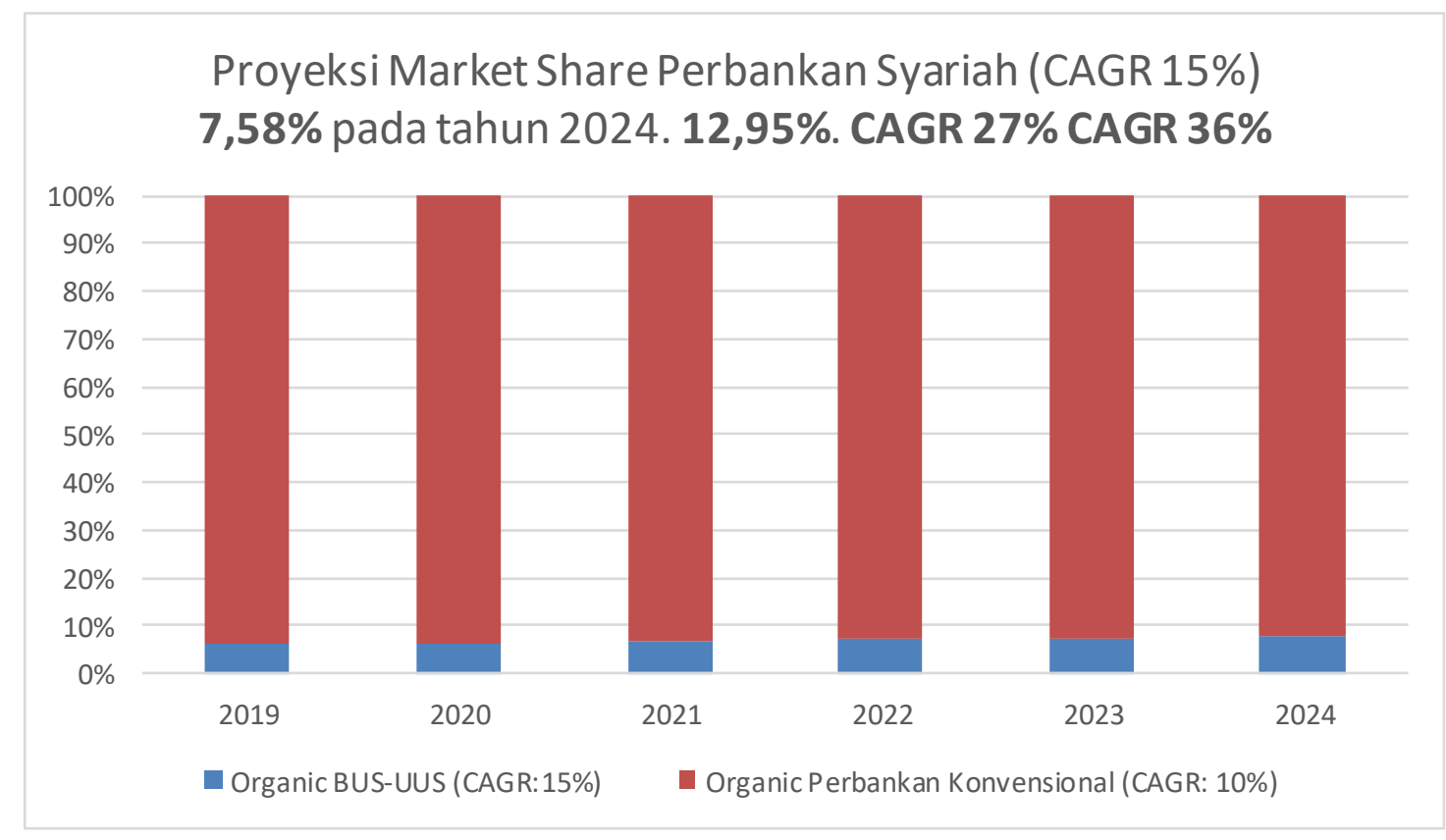

Gambar 3. Proyeksi Market Share Perbankan Syariah

Sumber: Komite Nasional Keuangan Syariah (2019)

Jika sektor perbankan syariah dibebaskan tumbuh terorganisir dengan Laju Pertumbuhan Majemuk Tahunan (CAGR) sebesar 15\% dan pada bank konvensional diasumsikan sebesar 10\%, bisa diproyeksikan dari total 
aset termasuk bank terbesar secara nasional dari segi aset. Dengan begitu, target dari aset keseluruhan yang semestinya dicapai oleh perbankan syariah adalah sebesar Rp290,29 triliun yang nantinya menjadikan perbankan syariah mampu untuk menduduki posisi sepuluh besar perbankan ditingkat nasional (Komite Nasional Keuangan Syariah, 2019). Dari tiga BUS plat merah tersebut, aset paling besar dipegang Bank Mandiri Syariah, disusul oleh BNI Syariah serta BRI Syariah. Jika diproyeksikan setelah proses hukum merger selesai, maka diperkirakan merger pada triwulan ke-I tahun 2021 bakal mengantongi aset sebesar Rp220-225 triliun (Lokadata.id, 2020). Untuk mengetahui total aset perbankan syariah peserta merger pada semester ke-I di tahun 2020, bisa dilihat pada Tabel 3.

Tabel 3. Total Aset Perbankan Syariah Peserta Merger

\begin{tabular}{cc}
\hline Nama Bank & Total Aset (Triliun Rupiah) \\
\hline BSM & 114 \\
BNIS & 50,76 \\
BRIS & 49,6 \\
Total & $\mathbf{2 1 4 , 3 6}$ \\
\hline
\end{tabular}

Sumber: Lokadata.id (2020)

Salah satu penggerak dari sektor riil dari sebuah negara yang memegang peran penting bagi pertumbuhan ekonomi adalah sektor keuangan. Besarnya aset pada bank akan memudahkan perbankan untuk melakukan ekspansi usaha. Jika dengan melakukan merger bank akan bertambah asetnya, maka akan bertambah besar pula usaha-usaha yang dimiliki oleh perbankan syariah. Besarnya usaha perbankan syariah akan mempengaruhi perekonomian di Indonesia. Pembiayaan perbankan syariah berpengaruh positif terhadap PDB sektor riil karena jika semakin banyak pembiayaan dari perbankan syariah ini disalurkan, maka modal pada usaha terutama UMKM akan meningkat pula.

Dari hal tersebut bisa membuat meningkatnya perekonomian dari sektor riil yang juga akan timbul peningkatan pada aktivitas ekonomi dan meningkatkan PDB (El Ayyubi et al., 2017). Terlebih di masa pandemi COVID19 ini banyak usaha yang membutuhkan pembiayaan sehingga bisa menjadikan perbankan syariah melakukan perluasan pembiayaan. Dari sinilah perbankan syariah akan memperbaiki perekonomian Indonesia pada masa pandemi COVID-19.

\section{Perluasan Penetrasi Pasar}

Jika jaringan pada perbankan syariah semakin meluas, otomatis perbankan syariah juga bisa untuk mendapatkan nasabah baru yang lebih 
banyak lagi dengan pangsa pasar yang telah tersedia. Seperti yang sudah diproyeksikan oleh KNKS pada gambar di subbab sebelumnya bahwa market share merger perbankan syariah milik negara pada tahun 2024 diperkirakan dapat mencapai 7,58\%. Menurut Ihalaw (2017), hal yang dapat dilakukan untuk merealisasikan penetrasi pasar adalah dengan mempertahankan pelanggan, dalam konteks ini adalah mitra.

Jika dilakukan merger pada perbankan syariah, maka berbagai inovasi baru bisa semakin bertambah dan dapat menarik perhatian dari para calon mitra untuk menjadi mitra. Dengan merger akan memudahkan untuk added value untuk membangun kemitraan nasabah. Misalkan dengan beragamnya produk usaha seperti wholesale, retail, sampai UMKM. Jika angka penetrasi pasar sudah tinggi, maka produk-produk dari perbankan syariah akan memiliki keunggulan tersendiri. Dari situlah akan meningkatkan kualitas dari hasil merger perbankan syariah yang tentunya dapat meningkatkan pula laju perekonomian di Indonesia terutama di tengah bencana pandemi COVID-19 seperti ini karena seperti UMKM yang telah menaruh amanah penuh untuk melakukan transaksi pada perbankan syariah.

\section{Efisiensi Biaya Pembiayaan}

Efisiensi dalam merger perbankan syariah tentunya akan terjadi karena dapat menciptakan entitas baru yang semakin gesit dan kompetitif dalam menjalankan operasionalnya. Dengan merger, maka perbankan syariah mampu untuk mengatasi tingginya beban seperti biaya operasional, capital expenditure, dan biaya seperti penggalangan DPK yang nantinya dapat ditekan. Dengan adanya kebijakan stimulus perekonomian nasional yang tertera pada POJK Nomor 11/POJK.03/2020 (Otoritas Jasa Keuangan, 2020b) membuktikan bahwa pemerintah tengah berupaya untuk menstabilkan sektor keuangan akibat pandemi COVID-19. Kebijakan ini akan memberikan arahan kepada lembaga perbankan untuk melakukan penggabungan, peleburan, pengambil alihan, dan/atau integrasi yang bertujuan untuk menjaga stabilitas sistem keuangan dalam kondisi pandemi.

Hal inilah yang dapat menjadi acuan untuk melakukan merger pada perbankan syariah. Jika merger telah dilakukan, maka akan memperkuat sistem keuangan syariah yang otomatis juga akan lebih mengefisienkan lagi dalam melakukan pembiayaan kepada mitra. Melalui kebijakan OJK diatas juga membuat perbankan syariah berusaha untuk mengupayakan relaksasi pembiayaan melalui beberapa metode seperti:

\section{a. Rescheduling}

Rescheduling ini berupa perpanjangan masa pembayaran (term) tanpa merubah jumlah yang harus dibayarkan (selling or agreed price).

b. Reconditioning (Restrukturisasi) 
Reconditioning ini berupa perubahan dalam suatu pembiayaan Islam secara prinsip, termasuk perubahan dalam struktur (akad yang digunakan), besaran margin (profit rate) atau klausul utama dari kontrak tersebut.

Kedua metode diatas berlaku pada pembiayaan yang telah dikeluarkan oleh perbankan syariah. Namun, solusi ini tidak dapat dilakukan secara berkelanjutan dan bersifat sementara. Kebijakan ini juga mampu untuk membantu UMKM dalam melanjutkan usahanya di masa yang sulit seperti ini seperti yang telah dilakukan oleh BRIS dalam merestrukturisasi pembiayaan kepada 29.000 mitra yang terdampak COVID-19. Selain meringankan mitra, cara ini juga dilakukan oleh perbankan syariah untuk dapat menekan rasio financing problem atau NPF agar tetap sesuai dengan ketentuan yang berlaku yaitu dibawah $5 \%$.

Salah satu bank syariah yang telah melakukannya adalah BRIS. Pada bulan Juni 2020, NPF dari BRIS menduduki rentang angka 3,5-4\% karena bank tersebut telah melakukan penataan pembiayaan kembali kepada 29.000 mitra sebesar Rp5,4 triliun. Sedangkan peserta merger lainnya yaitu BNIS memegang NPF sebesar 3,8\% pada kuartal pertama tahun 2020 dan BSM memiliki NPF sebesar 2,57\% (gross) serta 0,88\% (nett) pada semester pertama tahun 2020 (Ubaidillah \& Aji, 2020). Hal ini dapat lebih diperkuat lagi jika dilakukan merger karena resktrukturisasi pembiayaan bisa dilakukan dengan lebih mudah dan efisien karena jumlah aset bertambah. Selain dari perbankan syariah, peraturan dari OJK yang tertera pada POJK Nomor 34/POJK.3/2020 (Otoritas Jasa Keuangan, 2020c) yang memberikan relaksasi bagi Bank Pembiayaan Rakyat Syariah (BPRS) dengan tidak memberatkan perhitungan penyisihan penghapusan aset produktif umum, nilai agunan yang diambil alih sebagai faktor pengurang modal inti dalam perhitungan Kewajiban Penyediaan Modal Minimum (KPMM), serta penyediaan dana dalam bentuk penempatan dana antar bank.

Itulah beberapa peluang yang akan didapatkan oleh perusahaan perbankan jika melakukan kebijakan merger dengan perusahaan yang lain. Prediksi mengenai peluang tersebut telah mendukung penelitian sebelumnya yang telah dilakukan oleh Usmany (Usmany \& Badjra, 2019) yang mengatakan bahwa salah satu peningkatan nilai yang didapatkan oleh perbankan setelah melakukan kebijakan merger yaitu terjadi peningkatan kinerja finansial pada perbankan yang salah satu pembuktiannya dapat diuji melalui berbandingan rasio keuangan internal bank seperti Rasio Pengembalian Atas Aset (ROA), Rasio Kecukupan Modal (CAR), Rasio Pinjaman Terhadap Simpanan (LDR), dan juga Angka Pinjaman Macet (NPL) yang dibandingkan antara sebelum merger dengan sesudah merger. 


\section{Tantangan Merger Bank Syariah}

1. Risiko Pembiayaan

Keberhasilan progam pembiayaan di perbankan syariah dari mudharib (debitur) ke pihak shohibul mal (rekan yang melakukan pemberian pembiayaan) terpaut dalam bagaimana kemampuan mudharib melaksanakan kegiatan usahanya, apakah kegiatan usahanya terorganisir dengan lancar atau justru sebaliknya. Di masa pandemi COVID-19 ini membuat kondisi pasar menjadi kurang stabil. Salah satu kondisi pasar saat ini yaitu banyak perusahaan yang terkena dampak dari pandemi COVID-19.

Mereka yang terdampak harus mempertahankan bisnisnya bahkan bagi yang tidak bisa bertahan terpaksa untuk menghentikan operasionalnya. Hanya segelintir perusahaan saja yang dapat bertahan dengan adanya pandemi COVID-19 ini seperti perusahaan yang bergerak pada industri food and beverage, industri telekomunikasi, peralatan kesehatan yang dibutuhkan tenaga medis, serta pertanian dan perkebunan. Walaupun sudah ada undangundang yang mengatur tentang restrukturisasi pembiayaan yang bertujuan untuk memudahkan angsuran pembiayaan bagi mitra, bank syariah harus tetap berhati-hati dalam memutuskan untuk memberikan pembiayaan kepada mitra dengan cara lebih selektif dalam memilih calon mitra yang sekiranya usahanya mampu untuk bertahan di tengah pandemi COVID-19.

2. Risiko Operasional

Dampak yang berupa masalah dalam internal peserta merger juga dapat terjadi pada kebijakan penggabungan perbankan syariah milik negara karena dengan adanya kebijakan merger ini, komposisi dewan direksi yang menjabat sebagai pemimpin perbankan akan dikerucutkan dan jumlahnya akan menjadi sedikit. Dari pengerucutan ini kemungkinan besar juga akan berdampak pada lepasnya jabatan dari beberapa direksi yang telah menjabat sebelumnya. Hal ini juga bisa terjadi pada tingkatan yang lain seperti contohnya pada tingkat manajerial (manajemen tingkat tengah). Agar operasional usaha pascamerger tidak terganggu, pemerintah harus bisa menghilangkan konflik internal yang terjadi antara peserta merger (Wiratmini, 2020). Disisi lain, adanya kebijakan dari pemerintah untuk menanggulangi pandemi COVID-19 seperti Pembatasan Sosial Berskala Besar (PSBB) mengakibatkan masyarakat (termasuk para mitra dari perbankan syariah) lebih banyak menghabiskan waktunya untuk beraktifitas di dalam rumah seperti Work From Home (WFH) karantina mandiri, dsb, sehingga ini juga menjadi tantangan baru bagi perbankan syariah yang harus tetap melayani mitranya walaupun tidak secara tatap muka/offline.

Itulah beberapa tantangan yang akan didapatkan oleh perusahaan perbankan jika melakukan kebijakan merger dengan perusahaan yang lain. Prediksi mengenai tantngan tersebut telah mendukung penelitian 
sebelumnya yang telah dilakukan oleh Noegroho (Noegroho, 2017) yang mengatakan bahwa dalam melakukan sebuah merger, perusahaan khususnya perbankan akan menghadapi beberapa risiko salah satunya risiko operasional seperti diferensiasi budaya atau kultur yang disebabkan oleh adanya peretemuan dari dua atau lebih perusahaan yang berbeda dari segi kebiasaaan, nilai, bahkan bisa juga negaranya.

\section{KESIMPULAN}

Jumlah perbankan syariah di Indonesia akhir-akhir ini terus bertambah. Selain dari segi jumlah perusahaannya, tingkat aset, Dana Pihak Ketiga (DPK), Pembiayaan Yang Diberikan (PYD), dan juga Capital Adequacy Ratio (CAR) pada perbankan syariah juga turut mengalami peningkatan. Sementara Non Performing Financing (NPF) pada perbankan syariah mengalami penurunan (Sebuah peningkatan). Dari sini dapat disimpulkan bahwa meskipun di masa pandemi COVID-19 tidak membuat industri perbankan Syariah, termasuk Bank Syariah Mandiri (BSM), BNI Syariah (BNIS), dan BRI Syariah (BRIS) sebagai Bank Umum Syariah (BUS) peserta merger, mengalami kemerosotan.

Dengan adanya merger pada ketiga perbankan syariah milik negara, maka akan memiliki beberapa peluang diantaranya adalah meningkatnya aset pada perbankan syariah khususnya bagi peserta merger karena sudah otomatis ketika sebuah perusahaan digabung maka asetnya juga akan di akumulasi. Selain itu, dengan adanya kebijakan ini maka akan memperluas penetrasi pasar karena jika dilakukan merger pada perbankan syariah, maka berbagai inovasi baru bisa semakin bertambah dan dapat menarik perhatian dari para calon mitra untuk menjadi mitra. Peluang ketiga yang akan dimiliki oleh perbankan syariah peserta merger adalah semakin efisiennya biaya pada pembiayaan karena dengan merger, maka perbankan syariah mampu untuk mengatasi tingginya beban seperti biaya operasional, capital expenditure, dan biaya seperti penggalangan DPK yang nantinya dapat ditekan.

Disisi lain, adanya merger pada ketiga perbankan syariah milik negara ini ternyata juga akan menimbulkan banyak tantangan mengingat merger dilakukan di tengah bencana pandemi COVID-19 berlangsung, diantaranya adalah adanya risiko pembiayaan oleh perbankan itu sendiri mengingat COVID-19 membuat perekonomian di Indonesia, khususnya bagi pada pemilik UMKM maupun perusahaan besar terguncang. Maka dari itu, bagi perbankan syariah harus berhati-hati dalam memutuskan untuk memberikan pembiayaan kepada mitra dengan cara lebih selektif dalam memilih calon mitra yang sekiranya usahanya mampu untuk bertahan di tengah bencana pandemi COVID-19 agar tidak terjadi financing problem di waktu yang akan datang. Selain risiko pembiayan, risiko operasional juga menjadi tantangan bagi perbankan syariah peserta merger mengingat adanya kebijakan dari pemerintah untuk menanggulangi pandemi COVID-19 seperti Pembatasan Sosial Berskala Besar (PSBB) yang mengakibatkan masyarakat (termasuk para mitra dari perbankan syariah) megharuskan untuk lebih banyak menghabiskan waktu beraktifitasnya di dalam rumah seperti Work From 
Home (WFH) karantina mandiri, dsb, sehingga ini juga menjadi tantangan baru bagi perbankan syariah yang harus tetap melayani mitranya walaupun tidak secara tatap muka atau offline.

\section{SARAN}

Adanya kebijakan merger pada perbankan syariah milik negara menimbulkan peluang sekaligus tantangan yang besar. Peluang dan tantangan ini terutama disebabkan oleh faktor eksternal, yaitu adanya bencana pandemi COVID-19 mengingat kebijakan ini dilakukan disaat bencana pandemi COVID-19 sedang berlangsung. Dengan menganalisis risiko yang akan ditimbulkan oleh kebijakan tersebut, penulis merekomendasikan agar untuk meminimalisir adanya risiko pembiayaan seperti financing problem di waktu yang akan datang, bank syariah harus tetap berhati-hati dalam memutuskan untuk memberikan pembiayaan kepada mitra dengan cara lebih selektif dalam memilih calon mitra yang sekiranya usahanya mampu untuk bertahan di tengah bencana pandemi COVID-19. Karena bagi mitra yang terdampak pandemi COVID-19 bisa dipastikan bahwa operasional dari perusahaannya juga ikut terdampak. Sedangkan rekomendasi untuk meminimalisir adanya risiko operasional adalah dengan memasifkan atau menggencarkan aktifitas transaksi melalui media online seperti penggunaan M-Banking, Internet Banking, SMS Banking, dan juga memasifkan peran media sosial seperti Instagram, Facebook, dsb guna menyampaikan informasi kepada mitranya mengingat adanya kebijakan Pembatasan Sosial Berskala Besar (PSBB) yang mengakibatkan masyarakat (termasuk para mitra dari perbankan syariah) mengharuskan untuk lebih banyak menghabiskan waktu aktifitasnya dalam rumah.

\section{DAFTAR PUSTAKA}

Alfi, A. N. (2020). Aset Perbankan Syariah Tetap Bertumbuh di Tengah Pandemi.Bisnis.Com.

https://finansial.bisnis.com/read/20200923/231/1295698/asetperbankan-syariah-tetap-bertumbuh-di-tengah-pandemi

Amalia, F., \& Ika, S. R. (2014). Kinerja Bank Di Indonesia Setelah Melakukan Merger Dan Akuisisi Dengan Kepemilikan Asing : Apakah Lebih Baik? Efektif: Jurnal Bisnis Dan Ekonomi, 5(1), 73-84.

Badan Pemeriksa Keuangan. (2020). Peraturan Pemerintah (PP) Nomor 21 Tahun 2020 tentang Pembatasan Sosial Berskala Besar dalam Rangka Percepatan Penanganan Corona Virus Disease 2019 (COVID-19). Badan Pemeriksa Keuangan.

https://peraturan.bpk.go.id/Home/Details/135059/pp-no-21-tahun2020

Badan Pusat Statistik. (2020). Laporan Perekonomian Indonesia 2020. https://www.bps.go.id/publication/2020/09/16/be7568ad496829f35 
cea4b27/laporan-perekonomian-indonesia-2020.html

Bank Indonesia. (2020). Tingkat Inflasi Bulanan Indonesia selama pandemi COVID 19 (Persen). https://www.bi.go.id/id/default.aspx

Bank Negara Indonesia Syariah. (2020). Laporan Tahunan Bank Negara Indonesia (BNI) Syariah.

Bank Rakyat Indonesia Syariah. (2020). Laporan Tahunan Bank Rakyat Indonesia (BRI) Syariah.

Bank Syariah Mandiri. (2020). Laporan Tahunan Bank Syariah Mandiri (BSM). Bryman and Bell. (2003). Busisess Research Methods. Oxford University Press.

El Ayyubi, S., Anggraeni, L., \& Mahiswari, A. D. (2017). Pengaruh Bank Syariah terhadap Pertumbuhan Ekonomi di Indonesia. Jurnal Al-Muzara'ah, 5(2), 88-106.

Google News. (2020). Virus corona (COVID-19).

https://news.google.com/covid19/map?hl=id\&mid=\%2Fm\%2F03ryn\& $\mathrm{gl}=\mathrm{ID} \& \mathrm{ceid}=\mathrm{ID} \% 3 \mathrm{Aid}$

Goutama. (2020). Kebijakan Bank Indonesia dalam Upaya Stabilitas Rupiah di Masa Pandemi. Suara.Com.

https://yoursay.suara.com/news/2020/11/03/103719/kebijakan-

bank-indonesia-dalam-upaya-stabilitas-rupiah-di-masapandemi?page $=$ all

Hartomo, G. (2020). Ekonomi Lemah Imbas Corona, Sri Mulyani Beberkan 4 Sektor yang Paling Terancam. Okezone.Com.

https://economy.okezone.com/read/2020/04/01/20/2192215/ekono mi-lemah-imbas-corona-sri-mulyani-beberkan-4-sektor-yang-palingterancam

Ibeng, P. (2021). Pengertian Merger, Jenis, Tujuan, Contoh dan Menurut Ahli. Pendidikan.Co.Id.

https://pendidikan.co.id/pengertian-merger-jenis-tujuan-contoh-danmenurut-ahli/

Kementerian Kesehatan Republik Indonesia. (2020). FAQ. https://www.kemkes.go.id/folder/view/full-content/structurefaq.html

Kementerian Ketenagakerjaan Republik Indonesia. (2020). Menaker Ida Fauziyah Minta Pengusaha Jadikan PHK Sebagai Langkah Terakhir. Biro Humas Kemnaker.

https://kemnaker.go.id/news/detail/menaker-ida-fauziyah-mintapengusaha-jadikan-phk-sebagai-langkah-terakhir

Komite Nasional Keuangan Syariah. (2019). Kajian Konversi, Merger, Holding, dan Pembentukan Bank BUMN Syariah. Komite Nasional Keuangan Syariah.

Line Siaga. (2020). Bersama \#SiagaCOVID19. https://siaga.line.me/covid19?utm_source=line-oasiaga\&utm_medium=rich-message\&utm_campaign=daily-12-16

Lokadata.id. (2020). Melihat pro kontra merger bank syariah BUMN. Lokadata.Id.

https://lokadata.id/artikel/melihat-pro-kontra-merger-bank-syariahbumn 
Alfany A.A. Fiqri: Peluang dan Tantangan Merger Bank Syariah

Noegroho, I. (2017). Merger Merupakan Tantangan Atau Peluang Bagi Perekonomian Indonesia. Jurnal Penelitian Ekonomi Dan Akuntansi, 2 (3), 12.

Okalesa, Efni, Y., \& Zulbahridar. (2014). Analisis Perbandingan Kinerja Keuangan Perusahaan Perbankan Yang Go Public Di Bursa Efek Indonesia Sebelum Dan Setelah Merger Dan Akuisisi Periode Tahun 2000-2012. Jurnal Tepak Manajemen Bisnis, VI (3), 90-105.

Otoritas Jasa Keuangan. (2020a). Bank Umum. Otoritas Jasa Keuangan (OJK). https://www.ojk.go.id/id/kanal/perbankan/Pages/Bank-Umum.aspx

Otoritas Jasa Keuangan. (2020b). Peraturan Otoritas Jasa Keuangan Nomor 11/POJK.03/2020 tentang Stimulus Perekonomian Nasional sebagai Kebijakan Countercyclical Dampak Penyebaran Coronavirus Disease 2019 (POJK Stimulus Dampak COVID-19). Otoritas Jasa Keuangan (OJK).

Otoritas Jasa Keuangan. (2020c). Peraturan Otoritas Jasa Keuangan Nomor 34/POJK.03/2020 tentang Kebijakan bagi Bank Perkreditan Rakyat dan Bank Pembiayaan Rakyat Syariah Sebagai Dampak Penyebaran Corona Virus Disease 2019 Peraturan Pemerintah No. 28 Tahun 1999 tentang Merger, Konsolidasi. Otoritas Jasa Keuangan (OJK).

Otoritas Jasa Keuangan. (2020d). Sejarah Perbankan Syariah. Otoritas Jasa Keuangan (OJK). https://www.ojk.go.id/id/kanal/syariah/tentangsyariah/Pages/Sejarah-Perbankan-Syariah.aspx

Otoritas Jasa Keuangan. (2020e). Statistik Perbankan Syariah Indonesia. https://www.ojk.go.id/id/kanal/syariah/data-dan-statistik/statistikperbankan-syariah/default.aspx

Pradana, A. A., Casman, \& Nur'aini. (2020). Pengaruh Kebijakan Social Distancing pada Wabah COVID-19 terhadap Kelompok Rentan di Indonesia. Jurnal Kebijakan Kesehatan Indonesia: JKKI, 9(2), 61-67. https://jurnal.ugm.ac.id/jkki/article/view/55575

PS, A. P. (2018). Pengaturan Penggabungan Usaha (Merger) Bank Sebagai Upaya Peningkatan Kesehatan Bank Di Indonesia Dalam Pembangunan Hukum Ekonomi Nasional. Aktualita (Jurnal Hukum), 1(1), 1-15.

Sipangkar, Y. H., \& Sihaloho, E. D. (2020). Analisis efisiensi industri perbankan Indonesia setelah merger dan akuisisi: Pendekatan data envelopment analysis. Jurnal Manajemen Maranatha, 19 (2), 159-168.

The Gobal Economy. (2020). Indonesia: Purchasing Managers Index (PMI), manufacturing.

https://www.theglobaleconomy.com/Indonesia/pmi_manufacturing/

Ubaidillah, M., \& Aji, R. H. S. (2020). Tinjauan Atas Implementasi Perpanjangan Masa Angsuran Untuk Pembiayaan Di Bank Syariah Pada Situasi Pandemi Covid-19. Islamic Banking: Jurnal Pemikiran Dan Pengembangan Perbankan Syariah, 6(1), 1-16.

Usmany, L. R., \& Badjra, I. B. (2019). Perbedaan Kinerja Keuangan Bank Ocbc Nisp Sebelum Dan Sesudah Merger Di Indonesia. 8 (8), 5036-5059.

Wiratmini, N. P. E. (2020). Merger Bank Syariah BUMN, Semua Karyawan Diangkut jadi Keluarga Besar. Bisnis.Com.

https://finansial.bisnis.com/read/20201013/231/1304453/mergerbank-syariah-bumn-semua-karyawan-diangkut-jadi-keluarga-besar 